\title{
CHEMICAL CHANGES IN THE BLOOD AND THE OCCURRENCE OF URAMIA FOLLOWING HEAD INJURY
}

\author{
BY \\ J. N. CUMINGS \\ * From the Biochemical Department, National Hospital, Queen Square, London, W.C.1, \\ and the Central Pathological Laboratory, Sector 9, E.M.S.
}

(RECEIVED 14TH MAY, 1942)

URAMIA as a complication of crush injuries of the limbs is now well known and the histology of the renal lesion has been well described by Bywaters and Dible (1942). The occurrence of uræmia as a complication of head injuries without damage to any other part of the body has not been recognized. This paper describes firstly the results of an investigation begun in 1940 into alterations of various chemical constituents of the blood in patients with head injury only, but in whom no estimate of renal function was made, and secondly the results of renal function tests in 13 patients together with the findings in four cases of uræmia following head injury.

\section{Biochemical Changes in the Blood (excluding Renal Function Tests)}

Material and Methods.-Twenty-five patients admitted to various hospitals with head injury were examined. The degree of severity of the injury and the length of time of unconsciousness varied considerably, but the injury was limited to the head in every case. The injuries were related to air raid, road, gun, and explosive accidents. Blood was obtained at varying intervals after the injury, this time factor depending upon the advisability of vein puncture in regard to the clinical condition of the patient, and also upon the fact that patients were transferred from one hospital to another more suited to deal with cranial lesions.

Estimations of the following constituents of the blood were made-serum potassium (Cumings, 1939), sodium (Woelfel, 1938), and hæmobilirubin, plasma chlorides (McCance and Shipp, 1933), and inorganic phosphate (Fiske and Subbarow, 1925). Hæmatocrit readings were made on the first few cases examined but as no significant variations from the normal were found the results are not recorded.

* An expenses grant was received from the National Hospital Research Funds, for which my thanks are due. 


\section{Results}

Table I gives the results obtained. They are recorded in three groups in order of the severity of the injury. The first group consists of those patients who had a short period of unconsciousness with a minor injury only, the second group of those with fracture of the skull and the last group consists of patients with cerebral contusion as well as fracture of the skull.

Table I.-Blood Chemistry in Head InJury

\begin{tabular}{|c|c|c|c|c|c|c|}
\hline $\begin{array}{c}\text { NO. OF } \\
\text { DAYS } \\
\text { AFTER } \\
\text { INJURY }\end{array}$ & $\begin{array}{l}\text { CLINICAL } \\
\text { CONDITION. }\end{array}$ & $\begin{array}{c}\text { SERUM } \\
\text { HAMOBILI- } \\
\text { RUBIN }\end{array}$ & $\begin{array}{l}\text { SERUM } \\
\text { POTAS- } \\
\text { SIUM }\end{array}$ & $\begin{array}{c}\text { SERUM } \\
\text { SODIUM }\end{array}$ & $\begin{array}{c}\text { PLASMA } \\
\text { CHLORIDES } \\
\text { AS NaCl }\end{array}$ & \begin{tabular}{|c|} 
PLASMA \\
INORGANIC \\
PHOSPHATE
\end{tabular} \\
\hline \multirow{2}{*}{$\begin{array}{l}2 \\
4\end{array}$} & \multirow{2}{*}{$\begin{array}{l}\text { Slight loss of conscious- } \\
\text { ness No bony injury .. } \\
\text { Slight concussion. No bony }\end{array}$} & $0 \cdot 4$ & - & $322 \cdot 0$ & $549 \cdot 9$ & $4 \cdot 4$ \\
\hline & & $0 \cdot 1$ & $16 \cdot 5$ & $329 \cdot 9$ & $577 \cdot 9$ & - \\
\hline 4 & 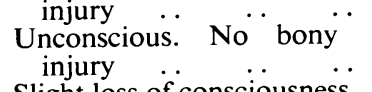 & $0 \cdot 3$ & $20 \cdot 1$ & $310 \cdot 5$ & $519 \cdot 5$ & $3 \cdot 6$ \\
\hline 6 & \multirow{3}{*}{$\begin{array}{l}\text { Slight loss of consciousness. } \\
\text { No bony injury ... } \\
\text { Slight unconsciousness. No } \\
\text { bony injury .. } \\
\text { Slight unconsciousness. No } \\
\text { bony injury .. } \\
\text { No unconsciousness. }\end{array}$} & - & $24 \cdot 3$ & 333.8 & $643 \cdot 5$ & $5 \cdot 5$ \\
\hline 9 & & 0.3 & $22 \cdot 8$ & $320 \cdot 0$ & $617 \cdot 7$ & $3 \cdot 0$ \\
\hline 9 & & $0 \cdot 1$ & $28 \cdot 1$ & - & $554 \cdot 6$ & $4 \cdot 1$ \\
\hline 10 & & $0 \cdot 15$ & 一 & - & $580 \cdot 3$ & $4 \cdot 0$ \\
\hline \multirow{3}{*}{$\begin{array}{l}4 \\
4 \\
6\end{array}$} & \multirow{2}{*}{ 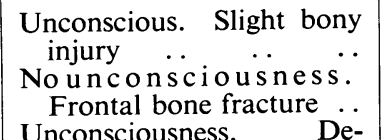 } & $0 \cdot 3$ & 18.9 & $329 \cdot 0$ & $503 \cdot 1$ & $4 \cdot 5$ \\
\hline & & $0 \cdot 1$ & $14 \cdot 1$ & $340 \cdot 0$ & $549 \cdot 9$ & $4 \cdot 0$ \\
\hline & $\begin{array}{l}\text { Unconsciousness. } \\
\text { pressed fracture }\end{array}$ & 0.3 & 14.9 & 338.0 & 578.0 & $3 \cdot 4$ \\
\hline 11 & $\begin{array}{c}\text { Unconscious. } \\
\text { fracture }\end{array}$ & 0.1 & $21 \cdot 4$ & 314.9 & $514 \cdot 8$ & $4 \cdot 87$ \\
\hline 12 & 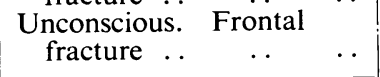 & $0 \cdot 1$ & $23 \cdot 7$ & 323.0 & $531 \cdot 2$ & $4 \cdot 3$ \\
\hline \multirow{4}{*}{$\begin{array}{l}1 \\
1 \\
2 \\
3 \\
4\end{array}$} & Severe cerebral contusion.. & 0 & $24 \cdot 1$ & - & $526 \cdot 5$ & - \\
\hline & $"$ & & $25 \cdot 6$ & $310 \cdot 6$ & $514 \cdot 8$ & $3 \cdot 5$ \\
\hline & , & & $26 \cdot 4$ & 294.4 & $\begin{array}{l}542.8 \\
528 .\end{array}$ & $\begin{array}{l}4 \cdot 7 \\
6 \cdot 4\end{array}$ \\
\hline & Severe cerëbral contusion & 0.25 & & $324 \cdot 2$ & 338.2 & \\
\hline \multirow[t]{2}{*}{4} & $\begin{array}{l}\text { with cerebral œdema } \\
\text { Severe cerebral contusion }\end{array}$ & 0.2 & $21 \cdot 4$ & - & 563.9 & - \\
\hline & $\begin{array}{l}\text { with cerebral herniation } \\
\text { Severe cerebral contusion }\end{array}$ & 0.5 & $14 \cdot 9$ & $328 \cdot 8$ & $580 \cdot 3$ & - \\
\hline 4 & $\begin{array}{l}\text { Severe cerebral contusion } \\
\text { with cerebral herniation } \\
\text { Severe }\end{array}$ & $1 \cdot($ & $23 \cdot 3$ & 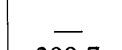 & $551 \cdot 8$ & 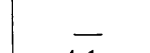 \\
\hline \multirow[t]{2}{*}{$\begin{array}{l}4 \\
4\end{array}$} & $\begin{array}{l}\text { Severe cerebral contusion } \\
\text { Subarachnoid hæmorrhage }\end{array}$ & $0 \cdot 3$ & $23 \cdot 7$ & $300 \cdot 7$ & $582 \cdot 0$ & $4 \cdot 1$ \\
\hline & $\begin{array}{l}\text { Subarachnoid hæmorrhage } \\
\text { with superficial injury .. } \\
\text { Unconscious. Fractured }\end{array}$ & $0 \cdot 3$ & $22 \cdot 8$ & $301 \cdot 9$ & $491 \cdot 4$ & $3 \cdot 97$ \\
\hline \multirow{4}{*}{$\begin{array}{l}6 \\
6 \\
8 \\
3\end{array}$} & $\begin{array}{l}\text { Unconscious. Fractured } \\
\text { base of skull }\end{array}$ & 0.1 & $20 \cdot 2$ & $301 \cdot 3$ & 468.0 & $4 \cdot 3$ \\
\hline & $\begin{array}{l}\text { Severe cerebral contusion } \\
\text { Severe cerebral contusion }\end{array}$ & $\begin{array}{l}0 \cdot 1 \\
0 \cdot 5\end{array}$ & $\overline{27 \cdot 7}$ & $\begin{array}{l}316 \cdot 8 \\
324 \cdot 0\end{array}$ & $\begin{array}{l}585 \cdot 0 \\
444 \cdot 6\end{array}$ & $\begin{array}{l}5 \cdot 4 \\
4 \cdot 7\end{array}$ \\
\hline & $\begin{array}{c}\text { Cerebral irritation. Un- } \\
\text { conscious }\end{array}$ & $0 \cdot 2$ & 21.8 & $300 \cdot 5$ & $477 \cdot 4$ & $5 \cdot 4$ \\
\hline & & & & & & \\
\hline
\end{tabular}

(All figures given in mgms. per cent.) 
There is some variation from the normal in all substances examined but there is no significant or constant change with the possible exception of the inorganic phosphate content, which tends to be raised in patients with severe cerebral contusion, more especially when the blood is examined several days after the injury. It would be of interest to know if the level of phosphate parallels the degree of demyelination of the cerebral tissue. The blood urea was not estimated in any of these patients. It may be that the raised level of phosphate in some of these 25 patients was associated with renal abnormality and not with demyelination. This is especially so in view of the blood urea levels found in the series to be recorded and also as in uræmia the phosphate level may be raised.

\section{Changes in the Blood and Urine in Uræmia Associated with Head Injury}

Material and Methods.-Seventeen further patients with injury limited to the head were investigated. The patients were carefully selected so that only those showing unconsciousness of some hours duration together with a marked degree of severity of cerebral damage were examined. Uræmia developed in four of these patients, three of whom died, and in two of these autopsy was performed. Investigation of the blood was made in all, and the urine was examined in as many patients as was possible, but three of the uræmic patients were incontinent, so making such examination difficult. Serum potassium, sodium and hæmobilirubin, plasma chlorides and inorganic phosphate, blood urea by Archer's modification of Folin and Wu's method (Harrison, 1937), and blood uric acid by a modification of King's et al method (1937) were estimated. Urea (Harrison, 1937), pH, inorganic phosphate, daily volume, albumen, and centrifuged deposit were estimated or examined for in such urine specimens as could be obtained.

Chemical analysis was performed on the kidneys removed at autopsy and the chloride, total phosphate, and uric acid contents estimated on the cortex and the medulla.

\section{Results}

Normal figures for blood urea were obtained in seven of the 17 patients, slightly raised levels in six, and a marked increase in the four patients who developed uræmia. Table II shows the results of the six cases in whom slightly increased blood urea figures were obtained.

The increase in blood urea is not marked but as the patients were young adults the figures are on the high side of normal, and this is confirmed in the one case examined nearly four weeks after the accident, by which time the blood urea had fallen to a normal figure. No other abnormalities were found in the investigations on these patients.

The chemical findings in the four cases of uræmia are given in Table III and short clinical abstracts will be found at the end of the paper. 
TABLE II

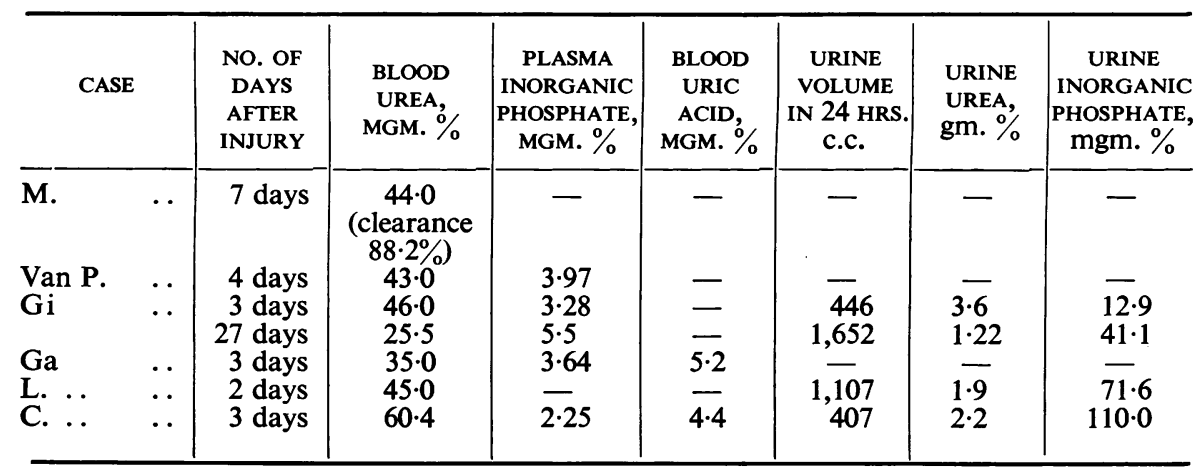

Incontinence of urine was present in three of these patients and in one there was anuria for the first day after the injury, so that urine analysis was difficult to perform satisfactorily. The kidneys of the two patients on whom autopsy was performed showed definite pathological lesions which are being described elsewhere, but which in the main consisted of degeneration of the proximal portion of the tubular epithelium at its point of exit from the glomerulus; in one case there were blood casts in the collecting tubules, features which are quite dissimilar to the changes seen in the kidneys from cases of traumatic anuria.

The most noticeable feature in the blood apart from the raised blood urea was the raised inorganic phosphate content. The urine specimens examined are remarkable for the high rate of excretion of urea with a reasonably concentrated urine, the degree of acidity of the urine, and in one case the low chloride content. The volume passed was about normal as far as could be determined by the degree of bed wetting as judged by a competent Sister.

The mechanism causing the renal lesion in traumatic anuria is unknown, and this is also the case in uræmia following head injury. Shaw Dunn et al. (1941) from observations on cases of crush injuries suggested the possibility that uric acid or phosphoric acid might have an ætiological significance, as the site of the renal lesion in their cases of traumatic anuria was similar to the renal lesion caused by these substances in experiments on animals. However, the site of the renal damage is not the same in head injury as in crush injuries of the limbs. Nevertheless, the head injury cases showed a raised plasma inorganic phosphate and in one case a raised blood uric acid level. It is possible that the damaged cerebral tissue liberates a substance containing phosphate, or that there is an alteration of an enzyme system which is concerned with the breakdown of such substances.

It was considered possible that an analysis of the renal tissue might yield interesting and instructive results, hence three normal kidneys and two from the patients on whom autopsies were performed were examined and Table IV shows the results obtained.

It is seen that in the cortex there is no significant difference between the normal and the abnormal kidneys, but the medulla shows a higher phosphate 


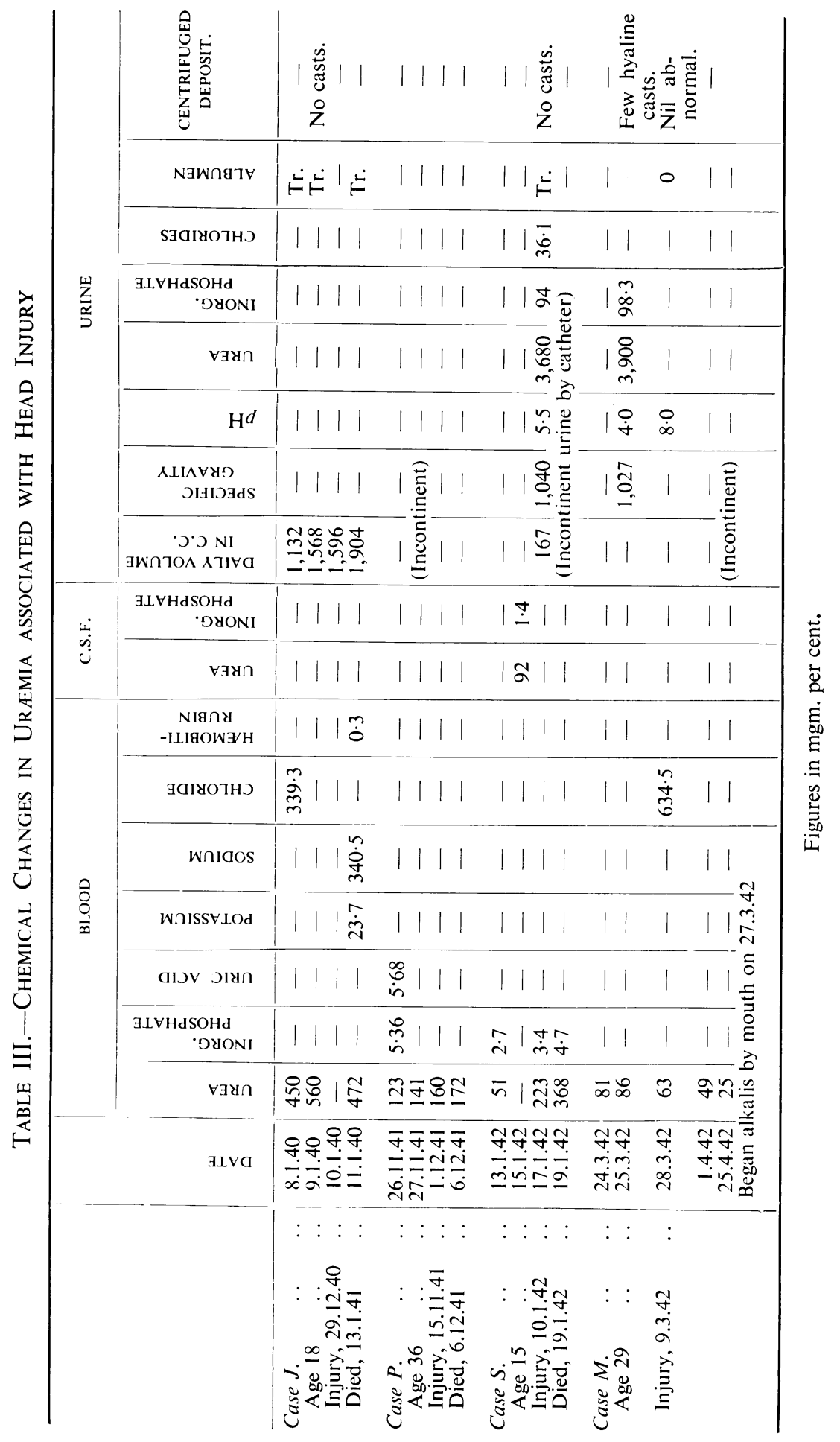


Table IV.-Chemical Analysis of Renal Tissue

\begin{tabular}{|c|c|c|c|c|c|c|c|}
\hline & & & CASE $P$. & CASE $S$. & NORMAL & NORMAL & NORMAL \\
\hline Cortex & $\begin{array}{l}\text { Chloride } \\
\text { Phosphate } \\
\text { Uric acid }\end{array}$ & $\begin{array}{l}. \\
\cdots \\
.\end{array}$ & $\begin{array}{l}1.41 \\
0.98 \\
-\end{array}$ & $\begin{array}{l}0.91 \\
1.09 \\
0.028\end{array}$ & $\begin{array}{l}1.3 \\
0.95 \\
-\end{array}$ & $\overline{\overline{\bar{C}}}$ & $\overline{\overline{\bar{C}}}$ \\
\hline Medulla & $\begin{array}{l}\text { Chloride } \\
\text { Phosphate } \\
\text { Uric acid }\end{array}$ & $\begin{array}{l}. \\
\cdots \\
.\end{array}$ & $\begin{array}{c}1.74 \\
0.95 \\
-\end{array}$ & $\begin{array}{l}0.71 \\
0.77 \\
0.067\end{array}$ & $\begin{array}{r}1.49 \\
0.45 \\
-\end{array}$ & $\overline{\overline{-}}$ & $\overline{\bar{Z}}$ \\
\hline
\end{tabular}

(Figures in gm. per cent.)

and uric acid content in the abnormal as compared to the normal kidney; however, the figures obtained as yet are too few to be of any definite assistance in demonstrating that either substance is an ætiological factor.

However, there are other points of difference between the cases of traumatic anuria and those described above. Bywaters and Dible state that in those cases adequately examined there was a low urea concentration with a dilute urine. The few examinations of the cases here recorded show a normal urea output in a urine markedly acid. It was thought, therefore, that such patients might be benefited by alkalies and the last patient (Case M.) was given large doses of potassium citrate and sodium bicarbonate by mouth. He responded well and immediately the blood urea began to fall and the clinical condition improved, although he is still suffering from the effects of the cerebral contusion he sustained.

\section{Summary}

The results of investigations into chemical changes of the blood and urine following head injury are recorded.

It is shown that plasma inorganic phosphate is raised in severe cerebral lesions and that in a few cases uræmia follows rapidly on cerebral injury. Such patients show raised blood urea and phosphate levels with a normal volume of urine, but with a high excretion of urea in an acid urine. Alkalies caused a clinical improvement in one patient with a raised blood urea.

Alterations in chemical content of phosphate and uric acid were found in the kidneys from two of the patients who died of uræmia.

I am indebted to the members of the Medical Staffs of the hospitals at which the patients were seen, and especially to Mr. Harvey Jackson, F.R.C.S. and Mr. E. B. C. Hughes, and also to Mr. R. Nunn, B.Sc. for technical help.

\section{APPENDIX}

\section{Clinical Notes of the Patients developing Uremia}

CASE J. Age 18. Air raid casualty on 29/12/40.

On admission to hospital the patient showed signs of shock and had severe scalp wounds only which were treated surgically, and with the local application of $\mathbf{M} \& \mathbf{B}$ 693. There was general improvement for 6 days but then vomiting commenced and 
continued for 2 days. The scalp wounds were now found to be infected, and drainage liberated pus.

The tongue was dry, blood pressure raised to $170 / 120$, with a heart of normal size, and the urine contained albumen. He slowly went downhill, becoming comatose and finally died $13 / 1 / 41$.

A fluid intake of between 1,600 and 2,000 c.c. a day was maintained with a good urinary output. No blood or serum transfusion was given, but intravenous saline and glucose were tried without any improvement in the condition of the patient.

There was no history of any previous renal lesion.

Autopsy was not performed.

(I am grateful to Dr. G. R. Steed for these notes.)

CASe P. Age 36. Road accident, 15/11/41.

The patient was admitted to hospital unconscious with bleeding from the ears and nose, and a slight degree of right-sided hemiplegia. He was incontinent. The heart was not enlarged and the blood pressure 130/90. A fractured skull and, in view of the continued unconsciousness, a subdural hæmatoma were diagnosed, but operation performed on $26 / 11 / 41$ revealed no blood in the subdural space.

He remained unconscious and showed no improvement until he died on 6/12/41.

At autopsy a fracture across the floor of the right middle fossa was found, but no hæmorrhage was present. No other injuries were found during life or at post mortem.

Case S. Age 15. Road accident, 10/1/42.

Admitted to hospital unconscious with a slow pulse and some bleeding from the nose and bruising over the back of the head. Pupils were pin-point but reacted to light. Some spacticity of the right side and flaccidity of the left. The C.S.F. was blood stained with slight increase of cells and protein.

He remained unconscious with plantar extensors and with some attacks of spasm in the legs and arms. The condition deteriorated until he died on 19/1/42.

At autopsy there was a fracture across the floor of the middle fossa with a little cerebral œdema, and a small amount of blood over the surface of the brain in the region of the fracture.

CASE M. Age 29. Road accident, 9/3/42.

On admission to hospital was unconscious, restless, and with a bruise over the occipital region and bleeding from the left ear. Still unconscious 11 days later, incontinent, but with no other abnormal neurological signs. Alkalies given on $27 / 3 / 42,8$ days later was improving clinically and after 10 days of treatment could obey commands, only slightly restless, and no abnormal physical signs were present.

\section{REFERENCES}

Bywaters, E. G. L., and Dible, J. H. (1942). J. Path. Bact., 54, 111.

Cumings, J. N. (1939). Biochem. J., 33, 642.

Dunn, J. S., Gillespie, M., and Niven, J. S. F. (1941). Lancet, 2, 549.

Fiske, C. H., and Subbarow, Y. (1925). J. biol. Chem., 66, 375.

Harrison, G. A. (1937). Chemical Methods in Clinical Medicine, Churchill, London.

King, E. J., Haslewood, G. A. D., and Delory, G. E. (1937). Lancet, 1, 886.

McCance, R. A., and Shipp, H. L. (1933). Chemistry of Flesh Food and their Losses on Cooking. Spec. Rep. Ser. M.R.C. No. 187.

Woelfel, W. C. (1938). J. biol. Chem., 125, 219. 